(c) American Dairy Science Association, 2003.

\title{
Influence of Nutrition Level on Digestibility in High Yielding Cows and Effects on Energy Evaluation Systems
}

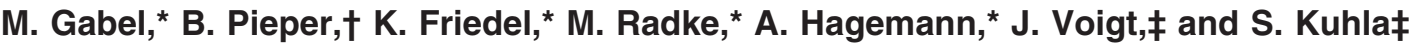 \\ *Institute for Ecologically-Compatible Animal Husbandry, University of Rostock, \\ D-18059 Rostock, Germany \\ tDr. Pieper Technology and Product Development, \\ D-16818 Wuthenow, Germany \\ łResearch Unit Nutritional Physiology "Oskar Kellner”, Research Institute for the Biology of Farm Animals, \\ D-18196 Dummerstorf, Germany
}

\begin{abstract}
The objective of the study was to determine the effect of nutrition level (NL, multiples of maintenance energy requirement) on the digestibility of nutrients for dairy cows regarding the energy supply of the animal. The digestion of nutrients and energy was investigated in two trials using lactating dairy cows. The NL varied from 2.7 to 5.0 using diets similar composition. In addition, sheep were given the same feed with a NL of 1.4. Digestibility of dry matter (DM) and all specific measures of dietary components declined significantly as NL increased. Digestibility of energy decreased by $4.1 \%$ for each increase in NL. The metabolizable energy, the ability to metabolize energy (metabolizable energy/ gross energy), and the content of net energy for lactation $\left(\mathrm{NE}_{\mathrm{L}}\right)$ per kilogram of $\mathrm{DM}$ intake were calculated for NL from 1 to 6 on the basis of these relationships and as well as the gross energy, methane energy, and urine energy. Accordingly the $\mathrm{NE}_{\mathrm{L}}$ content declined by 0.11 $\mathrm{MJ} / \mathrm{kg}$ of DM intake or $1.6 \%$ as the NL increased by one unit. It means that the $\mathrm{NE}_{\mathrm{L}}$ requirement above the maintenance requirement increased by $0.07 \mathrm{MJ}$ of $\mathrm{NE}_{\mathrm{L}}$ per kilogram of fat-corrected milk, if the NL increased by one unit.
\end{abstract}

(Key words: digestibility, nutrition level, net energy for lactation)

Abbreviation key: $\mathbf{E E}=$ ether extract, $\mathbf{G E}=$ gross energy, $\mathbf{M E}=$ metabolizable energy, $\mathbf{N L}=$ nutrition level.

\section{INTRODUCTION}

The energy concentration of different feeds is calculated on the basis of chemical composition and digestibility of nutrients; thereby the digestibility coefficients are determined in sheep given diets for maintenance

Received February 20, 2003.

Accepted June 16, 2003.

Corresponding author: M. Gabel; e-mail: martin.gabel@auf. uni-rostock.de.
(Schiemann, 1981). With the increasing performance of the dairy cow, feed intake rises but digestibility coefficients of nutrients and energy decrease (Brown, 1966; Schiemann et al., 1970; Colucci et al., 1982). The problem of decreasing digestibility of energy with rising nutrition level (NL, defined as the multiple of maintenance or total metabolizable energy [ME]/ME for maintenance) and the associated compensation of energy losses by concomitant reduction of the excretion of methane and urine (Schiemann et al., 1970, 1971) has been not extensively discussed. Different feed evaluation systems consider the incomplete compensation of energy loss by the decrease of digestibility with rising NL in different ways. In the German and English systems, the compensation results from an increment of the values of energy requirement by, respectively, $0.8 \%$ (GfE, 2001) and by $1.8 \%$ (AFRC, 1993) per NL above 1. In the American system (NRC, 2001) the compensation is implemented by altering the energetic feed value of the particular feeds. On average, a reduction of $8 \%$ of the tabulated value of total digestible nutrients at average production levels is considered, which comprise the NL 2 to 4 (average NL = 3). The energy contents of feedstuffs are specified for the three and four times maintenance intake, whereas no data are available for NL higher than 4.

Balance studies on dairy cows were described until a NL of 3 to 3.5 (Schiemann et al., 1970, 1971), respectively, a NL of 4 (Ekern, 1972). However, the current performance of dairy cows on NL 5 to 6 has to be considered. Research is needed to define the digestibility of nutrients of diets for high-yielding dairy cows. Our objectives were to determine the influence of $\mathrm{NL}$ on digestibility of diets and to discuss the consequences for calculation of energy requirement in high-yielding dairy cows.

\section{MATERIALS AND METHODS}

\section{Experimental Design}

The influence of the NL on the digestibility of nutrients was examined in two experiments using two almost identical feed rations (Tables 1 and 2). 
Diets. The ingredients and chemical parameter of diets are shown in Table 2.

\section{Feeding}

Wethers. After an adaptation period, a 14-d preliminary period was conducted feeding the respective experimental ration. To ensure the same ration composition for both wethers and cows, the rations for wethers (about DMI $21 \mathrm{~g} / \mathrm{kg}$ of BW) were prepared (single for each animal and each daily meal in closed polyethylene bag) together with the rations for cows and stored frozen $\left(-18^{\circ} \mathrm{C}\right)$ until the beginning of the trials. The frozen portions were thawed $24 \mathrm{~h}$ before feeding in closed bag at 18 to $20^{\circ} \mathrm{C}$. The daily diet was given in equal amounts at 0700 and $1600 \mathrm{~h}$. The diets were consumed completely by the animals. As shown by Beever et al. (1976) no influence of freezing and thawing procedures on digestibility is to be expected.

Dairy cows. Even though the cows were adapted to the ration, a preliminary period of $10 \mathrm{~d}$ was maintained. In experiment 1 , at the high NL (5), cows were fed ad libitum individually, allowing for $10 \%$ orts. At NL 3 and in experiment 2 , cows were restricted fed. The animals were fed twice daily (0700 and $1700 \mathrm{~h}$ ). The roughage (weighing precision $\pm 1 \mathrm{~g}$ ) and feed supplements (weighing precision $\pm 0.1 \mathrm{~g}$ ) were intensively mixed by hand before feeding. Remaining feed residues (experiment 1 , NL 5) were recorded daily and considered quantitatively for calculation of nutrient intake.

\section{Sampling and Sample Processing}

Feedstuffs. Samples of the feedstuffs were taken daily before mixing the rations. The samples were stored at $-18^{\circ} \mathrm{C}$ and composited at the end of the experiment to obtain an average sample. Silage samples were freeze-dried. Concentrate samples were dried at $65^{\circ} \mathrm{C}$ in an oven with constant airflow. The dried samples were ground over a 1-mm screen, air equilibrated, and stored until analysis.

Feces. The length of the collection was $7 \mathrm{~d}$ for wethers and $6 \mathrm{~d}$ for cows. The feces of the wethers were collected in special collection bags fixed on the animals with leather straps. Urine was not collected. The collection bags were emptied twice daily at feeding time. The daily collected feces per animal were stored at $0^{\circ} \mathrm{C}$ and mixed at the end of the experiment. Subsamples of mixed feces were used for DM determination and drying at $65^{\circ} \mathrm{C}$ in an oven with constant airflow. The dried feces was ground through a laboratory mill with a 1-mm sieve, air equilibrated, and stored until analysis.

Quantitative collection of feces in cows was manually done around-the-clock with buckets. Every single fecal sample was weighed (weighing precision $\pm 1 \mathrm{~g}$ ) and homogenized before an aliquot of $2 \%$ was taken to obtain a pooled sample. The pooled sample of feces was stored at $-18^{\circ} \mathrm{C}$ and used for $\mathrm{DM}$ determination and freezedrying. The dried samples were treated like the fecal samples from wethers.

\section{Analytical Methods}

Duplicate analyses were conducted for all estimated nutrients. Generally, the Weende feed analysis method (Naumann and Bassler, 1993) was applied. Determination of CP was conducted in samples of feed as well as in samples of feces by combustion analysis by Dumas using the equipment "elementar macro N" (Elementar Analysensysteme, Hanau, Germany). The ether extract (EE) determination was conducted with HCl-hydrolysis according to Kuhla et al. (1983). Starch content was determined by the method of Zwierz et al. (1981) using starch digestion by a thermostable amylase and anthrone sulfuric acid as indicator reagent. Both NDF and ADF were determined according to Goering and Van Soest (1970).

\section{Calculation of Energy Content}

The gross energy (GE) in feed was calculated by following equation:

$$
\begin{gathered}
\mathrm{GE}(\mathrm{MJ})=0.0239 \times \mathrm{CP}(\mathrm{g})+0.0398 \times \mathrm{EE}(\mathrm{g})+0.0201 \\
\times \mathrm{CF}(\mathrm{g})+0.0175 \times \mathrm{NFE}(\mathrm{g})(\mathrm{GfE}, 2001)
\end{gathered}
$$

where $\mathrm{CF}$ = crude fiber, $\mathrm{NFE}$ = nitrogen-free extract, and digestible energy (DE) was calculated using the digestible (d) nutrients as follows (Hoffmann and Schiemann, 1980):

Cattle:

$$
\begin{aligned}
\mathrm{DE}(\mathrm{MJ})= & 0.0242 \times \mathrm{dCP}(\mathrm{g})+0.0341 \times \mathrm{dEE}(\mathrm{g})+0.0185 \\
& \times \mathrm{dCF}(\mathrm{g})+0.0170 \times \operatorname{dNFE}(\mathrm{g})
\end{aligned}
$$

Sheep:

$\begin{aligned} \mathrm{DE}(\mathrm{MJ})= & 0.0239 \times \mathrm{dCP}(\mathrm{g})+0.0379 \times \mathrm{dEE}(\mathrm{g})+0.0183 \\ & \times \mathrm{dCF}(\mathrm{g})+0.0170 \times \mathrm{dNFE}(\mathrm{g}) .\end{aligned}$

The following equations were used to calculate the urinary and methane energy:

$$
\begin{gathered}
\text { Urinary energy }(\% \text { of GE) }=6.41-0.98 \times \mathrm{NL} \\
\text { (Schiemann et al., 1970) } \\
\text { Methane energy }(\% \text { of GE) }=11.26-1.28 \times \mathrm{NL} \\
\text { (Schiemann et al., 1970) }
\end{gathered}
$$


Table 3. Digestibility of nutrients $(\%)$ in experiment 1 (means $\pm \mathrm{SD} ; \mathrm{n}=8$ ).

\begin{tabular}{llll}
\hline Item & $\mathrm{NL}=5.0^{1}$ & $\mathrm{NL}=2.8^{1}$ & $\mathrm{NL}=1.4^{2}$ \\
\hline $\mathrm{DM}$ & $64.6^{\mathrm{a}} \pm 1.3$ & $70.0^{\mathrm{b}} \pm 0.9$ & $76.1^{\mathrm{c}} \pm 1.4$ \\
OM & $66.2^{\mathrm{a}} \pm 1.2$ & $72.3^{\mathrm{b}} \pm 0.9$ & $79.0^{\mathrm{c}} \pm 1.7$ \\
CP & $63.1^{\mathrm{a}} \pm 2.5$ & $67.7^{\mathrm{b}} \pm 2.0$ & $77.0^{\mathrm{c}} \pm 2.8$ \\
Crude fiber & $53.3^{\mathrm{a}} \pm 2.0$ & $65.6^{\mathrm{b}} \pm 1.1$ & $71.4^{\mathrm{c}} \pm 2.5$ \\
Ether extract & $57.4^{\mathrm{a}} \pm 1.5$ & $62.2^{\mathrm{a}} \pm 3.2$ & $68.7^{\mathrm{b}} \pm 2.1$ \\
Starch & $88.6^{\mathrm{a}} \pm 0.8$ & $90.8^{\mathrm{b}} \pm 1.2$ & $98.9^{\mathrm{c}} \pm 0.5$ \\
NFE & $71.5^{\mathrm{a}} \pm 0.8$ & $76.4^{\mathrm{b}} \pm 0.9$ & $82.7^{\mathrm{c}} \pm 2.3$ \\
NDF & $48.3^{\mathrm{a}} \pm 1.8$ & $59.0^{\mathrm{b}} \pm 1.1$ & $68.7^{\mathrm{c}} \pm 3.0$ \\
ADF & $48.8^{\mathrm{a}} \pm 2.7$ & $59.6^{\mathrm{b}} \pm 0.8$ & $68.5^{\mathrm{c}} \pm 2.9$ \\
Energy & $62.8^{\mathrm{a}} \pm 1.3$ & $68.7^{\mathrm{b}} \pm 1.0$ & $75.8^{\mathrm{c}} \pm 1.5$ \\
\hline
\end{tabular}

a,b,c Different letters within a row show significant differences $(P<0.05)$.

${ }^{1}$ Dairy cows. NL = nutrition level.

${ }^{2}$ Wethers.

\section{Statistical Treatment}

Calculation of digestibility parameters, arithmetic means, and their variance were conducted with the software package Excel 7.0 (Microsoft Corporation, Redmond, CA). Linear regression analysis and LSD test for tests of significance were performed with the software package SPSS 10.0 (SPSS Inc., Chicago, IL). Significant differences $(P<0.05)$ were indicated with different letters within a row.

\section{RESULTS}

Results of digestibility of nutrients obtained in experiment 1 are shown in Table 3. As expected, digestibility of the respective nutrient variable differs distinctly between the NL. These differences are significant $(P<$ 0.05), except for EE between NL 2.8 and 5.0.

Results of experiment 1 were generally verified by the findings of experiment 2 (Table 4). Differences shown in Table 4 are significant, except for digestibility of crude fiber, EE, and ADF between NL 1.4 and 2.7.

The results of the regression analysis of the dependence of digestibility on the NL is of importance and can be seen in Table 5. Given relationships vary $(P<$ $0.05)$ for all nutrients and energy. Regression coefficients for particular nutrients and energy show the varying degree of the negative effect of the NL on their digestibility. This tends to result in the following order:

$$
\begin{gathered}
\mathrm{NDF}>\mathrm{ADF}>\mathrm{CF}>\mathrm{CP}>\text { energy }>\mathrm{OM}>\mathrm{DM}>\mathrm{NFE}> \\
\mathrm{EE}>\text { starch. }
\end{gathered}
$$

\section{DISCUSSION}

According to the investigations of Brown (1966), Schiemann et al. (1971), and Colucci et al. (1982), the ration composition has a wide influence on the effect of NL on digestibility of both nutrients and energy. Therefore, the presented results were obtained with almost the same composition of the ration.

The results of our investigation (Tables 3 to 5 ) verify the relationship between digestibility of nutrients and of energy and the NL. The rate of depression in digestibility of energy amounted to 3.2 units, or $4.1 \%$, for each increase in NL. In a review, Tyrrell and Moe (1975) found a value of about $4 \%$ for total digestible nutrients. Finger et al. (1998) recently published similar findings

Table 4. Digestibility of nutrients $(\%)$ in experiment $2($ means $\pm \mathrm{SD} ; \mathrm{n}=8)$.

\begin{tabular}{llll}
\hline Item & $\mathrm{NL}=4.6^{1}$ & $\mathrm{NL}=2.7^{1}$ & $\mathrm{NL}=1.4^{2}$ \\
\hline DM & $67.2^{\mathrm{a}} \pm 1.2$ & $72.3^{\mathrm{b}} \pm 1.1$ & $74.8^{\mathrm{c}} \pm 0.4$ \\
OM & $69.0^{\mathrm{a}} \pm 1.2$ & $74.5^{\mathrm{b}} \pm 1.0$ & $77.5^{\mathrm{c}} \pm 0.4$ \\
CP & $66.3^{\mathrm{a}} \pm 1.3$ & $71.5^{\mathrm{b}} \pm 2.2$ & $78.3^{\mathrm{c}} \pm 2.7$ \\
Crude fiber & $57.4^{\mathrm{a}} \pm 1.9$ & $66.7^{\mathrm{b}} \pm 1.2$ & $68.9^{\mathrm{b}} \pm 1.1$ \\
Ether extract & $61.7^{\mathrm{a}} \pm 0.6$ & $64.3^{\mathrm{b}} \pm 1.6$ & $67.4^{\mathrm{b}} \pm 2.6$ \\
Starch & $91.1^{\mathrm{a}} \pm 2.0$ & $94.5^{\mathrm{b}} \pm 1.3$ & $98.7^{\mathrm{c}} \pm 0.6$ \\
N-free extract & $74.1^{\mathrm{a}} \pm 1.3$ & $78.6^{\mathrm{b}} \pm 0.9$ & $80.6^{\mathrm{c}} \pm 1.0$ \\
NDF & $52.9^{\mathrm{a}} \pm 1.2$ & $61.9^{\mathrm{b}} \pm 1.1$ & $65.3^{\mathrm{c}} \pm 0.9$ \\
ADF & $54.9^{\mathrm{a}} \pm 0.6$ & $63.6^{\mathrm{b}} \pm 2.3$ & $65.2^{\mathrm{b}} \pm 0.5$ \\
Energy & $65.4^{\mathrm{a}} \pm 1.4$ & $70.6^{\mathrm{b}} \pm 1.0$ & $74.1^{\mathrm{c}} \pm 0.4$ \\
\hline
\end{tabular}

${ }^{\mathrm{a}, \mathrm{b}, \mathrm{c}}$ Different letters within a row show significant differences $(P<0.05)$.

${ }^{1}$ Dairy cows. $\mathrm{NL}=$ nutrition level.

${ }^{2}$ Wethers. 
Table 5. Regression equations for dependence of digestibility of nutrients and energy (\%) on the nutrition level (measure range 1.4 to 5 ).

\begin{tabular}{llll}
\hline Nutrient/energy & Equation & Variance & $\begin{array}{c}\text { Coefficient of } \\
\text { determination }\end{array}$ \\
\hline DM & $=79.36-2.85 \times \mathrm{NL}$ & \pm 1.36 & $0.90(1)$ \\
OM & $=82.60-3.18 \times \mathrm{NL}$ & \pm 1.42 & $0.92(2)$ \\
CP & $=81.95-3.77 \times \mathrm{NL}$ & \pm 2.47 & $0.83(3)$ \\
Ether extract & $=71.26-2.58 \times \mathrm{NL}$ & \pm 2.34 & $0.72(4)$ \\
Crude fiber & $=77.53-4.54 \times \mathrm{NL}$ & \pm 2.07 & $0.91(5)$ \\
N-Free extract & $=85.23-2.64 \times \mathrm{NL}$ & \pm 1.56 & $0.86(6)$ \\
Starch & $=101.31-2.55 \times \mathrm{NL}$ & \pm 1.99 & $0.78(7)$ \\
NDF & $=74.20-4.95 \times \mathrm{NL}$ & \pm 2.34 & $0.91(8)$ \\
ADF & $=73.94-4.62 \times \mathrm{NL}$ & \pm 2.90 & $0.85(9)$ \\
Energy & $=79.15-3.21 \times \mathrm{NL}$ & \pm 1.39 & $0.92(10)$ \\
\hline
\end{tabular}

on the influence of increasing DMI of rations with identical composition but with or without the addition of partially protected fat on digestibility of nutrients and energy. In their study, the energy content decreased from 6.9 to $6.3 \mathrm{MJ}$ of $\mathrm{NE}_{\mathrm{L}} / \mathrm{kg}$ of $\mathrm{DMI}$ as level of DMI increased from 8.4 to $21.0 \mathrm{~kg} / \mathrm{d}$ per cow.

Utilizing the GE, urine energy, methane energy, and the equations [2] and [10] in Table 5 it is possible to calculate the energetic feed value for a ration with a composition according to experiment 1 and 2 (Table 2) at different NL (Table 6). Nevertheless, it has to be considered that the equations of urine energy and methane energy (Schiemann et al., 1970) experimentally represent the measured range of NL only from 1 to 3.5 . Data for NL 4, 5, and 6 are extrapolated due to the lack of data regarding these NL.

Metabolizable energy declines from $11.21 \mathrm{MJ} / \mathrm{kg} \mathrm{DM}$ at NL 1 to $10.48 \mathrm{MJ} / \mathrm{kg}$ DM at NL 6 (-0.15 MJ of ME/kg DM per NL; Table 6). The net energy content decreases from $6.81 \mathrm{MJ} / \mathrm{kg} \mathrm{DM}$ at NL 1 to $6.27 \mathrm{MJ} / \mathrm{kg} \mathrm{DM}$ at NL $6\left(-0.11 \mathrm{MJ}\right.$ of $\mathrm{NE}_{\mathrm{L}} / \mathrm{kg} \mathrm{DM}$ or $-1.6 \%$ per NL). This value corresponds to the correction value of $1.8 \%$ per NL used by the AFRC (1993).

In NRC (2001), which considers the effect of the decline of digestibility on the $\mathrm{NE}_{\mathrm{L}}$ content of the respective feedstuff, this correction value depends on the total digestible nutrients content of the feed. Thus, it rises with increasing total digestible nutrients content. For energy-rich feedstuffs, which are specifically fed to high-yielding dairy cows, this correction value amounts to 4.5 to $5.5 \%$ between the NL 3 and 4 .

An isolated comparison of the consideration of the remaining energetic impact of declining digestibility at rising NL in the different feed evaluation systems is complicated, because this impact has to be considered in context with the deduced and defined values for feed value as well as requirements of animals in the respective feed evaluation systems. This becomes particularly obvious in the review of Vermorel and Coulon (1998). The authors conclude that the $\mathrm{ME}$ and $\mathrm{NE}_{\mathrm{L}}$ values of feeds seemed overestimated by the United States system (NRC, 2001) compared with results using the Euro-

Table 6. Calculation of metabolizable energy (ME) and $\mathrm{NE}_{\mathrm{L}}$ content $(\mathrm{MJ} / \mathrm{kg} \mathrm{DM})$ of the experimental diets depending on the nutrition level.

\begin{tabular}{|c|c|c|c|c|c|c|}
\hline \multirow[t]{2}{*}{ Item } & \multicolumn{6}{|c|}{ Nutrition level } \\
\hline & 1 & 2 & 3 & 4 & 5 & $6^{1}$ \\
\hline Digestibility of OM, \% & 79.3 & 76.2 & 73.0 & 69.9 & 66.7 & 63.6 \\
\hline Digestibility of energy, $\%$ & 75.5 & 72.5 & 69.4 & 66.4 & 63.3 & 60.3 \\
\hline Gross energy (GE), MJ/kg DM & 18.65 & 18.65 & 18.65 & 18.65 & 18.65 & 18.65 \\
\hline Methane energy, $\%$ of GE & 9.98 & 8.70 & 7.42 & 6.14 & 4.86 & 3.58 \\
\hline Urinary energy, \% of GE & 5.43 & 4.45 & 3.47 & 2.49 & 1.51 & 0.53 \\
\hline Methane energy, MJ/kg DM & 1.86 & 1.62 & 1.38 & 1.15 & 0.91 & 0.67 \\
\hline Urine energy, MJ/kg DM & 1.01 & 0.83 & 0.65 & 0.46 & 0.28 & 0.10 \\
\hline Digestible energy (DE), MJ/kg DM & 14.08 & 13.51 & 12.95 & 12.38 & 11.81 & 11.25 \\
\hline $\mathrm{ME}, \mathrm{MJ} / \mathrm{kg} \mathrm{DM}^{2}$ & 11.21 & 11.06 & 10.92 & 10.77 & 10.62 & 10.48 \\
\hline$q=(\mathrm{ME} / \mathrm{GE}) \times 100$ & 60.1 & 59.3 & 58.5 & 57.7 & 57.0 & 56.2 \\
\hline $\mathrm{NE}_{\mathrm{L}}, \mathrm{MJ} / \mathrm{kg} \mathrm{DM}{ }^{3}$ & 6.81 & 6.70 & 6.59 & 6.48 & 6.37 & 6.27 \\
\hline
\end{tabular}

${ }^{1}$ Values for NL 6 were extrapolated, because no experimental data are available.

${ }^{2} \mathrm{ME}(\mathrm{MJ} / \mathrm{kg} \mathrm{DM})=\mathrm{DE}(\mathrm{MJ} / \mathrm{kg} \mathrm{DM})-($ methane energy $[\mathrm{MJ} / \mathrm{kg} \mathrm{DM}]+$ urinary energy $[\mathrm{MJ} / \mathrm{kg} \mathrm{DM}])$.

${ }^{3} \mathrm{NE}_{\mathrm{L}}(\mathrm{MJ})=0.6(1+0.004[\mathrm{q}-57]) \times \mathrm{ME}(\mathrm{MJ})$. 
Table 7. Calculation of milk production and $\mathrm{NE}_{\mathrm{L}}$ consumption for milk production depending on the energy concentration calculated for the nutrition levels 1 to $6 .^{1}$

\begin{tabular}{|c|c|c|c|c|c|c|}
\hline \multirow[b]{2}{*}{ Item } & \multicolumn{6}{|c|}{ Nutrition level } \\
\hline & 1 & 2 & 3 & 4 & 5 & 6 \\
\hline $\mathrm{NE}_{\mathrm{L}}, \mathrm{MJ} / \mathrm{kg} \mathrm{DM}$ & 6.81 & 6.70 & 6.59 & 6.48 & 6.37 & 6.27 \\
\hline $\mathrm{NE}_{\mathrm{L}}, \mathrm{MJ}$ at $25 \mathrm{~kg} \mathrm{DMI}$ & 170.2 & 167.5 & 164.7 & 162.0 & 159.3 & 156.8 \\
\hline $\mathrm{NE}_{\mathrm{L}}, \mathrm{MJ}$ for maintenance & 37.7 & 37.7 & 37.7 & 37.7 & 37.7 & 37.7 \\
\hline $\mathrm{NE}_{\mathrm{L}}, \mathrm{MJ}$ for milk production & 132.5 & 129.8 & 127.0 & 124.3 & 121.6 & 119.1 \\
\hline Milk yield kg/d, $3.14 \mathrm{MJ} / \mathrm{kg}^{2}$ & 42.2 & 41.3 & 40.4 & 39.6 & 38.7 & 37.9 \\
\hline $\begin{array}{l}\text { Conclusion for German system } \\
\text { (GfE,2001): } \\
\mathrm{NE}_{\mathrm{L}} \text { per kg milk based on } \mathrm{NE}_{\mathrm{L}} \text { intake at }\end{array}$ & & & & & & \\
\hline $\mathrm{NL}=1, \mathrm{MJ}$ & 3.14 & 3.21 & 3.28 & 3.35 & 3.42 & 3.49 \\
\hline DMI for $40 \mathrm{~kg}$ FCM, kg/d & 24.0 & 24.4 & 24.8 & 25.2 & 25.6 & 26.0 \\
\hline
\end{tabular}

${ }^{1}$ For explanation see text. Values for NL 6 were extrapolated, because no experimental data are available.

${ }^{2} 4.0 \%$ fat, $3.2 \%$ protein; MJ/kg Milk $=0.38 \times \%$ fat $+0.21 \times \%$ protein +0.95 (Tyrrell and Reid, 1965).

pean systems; however, the ratio of $\mathrm{NE}_{\mathrm{L}}$ to $\mathrm{TDN}$ was almost constant. As a consequence, the feed requirements were generally lower in the NRC system than in European systems, especially for higher milk production.

Transforming the reduction of digestibility by the NL as determined in the presented investigations onto a "standard cow" ( $650 \mathrm{~kg}$ of BW and 37.7 MJ maintenance requirement with $4.0 \%$ fat and $3.2 \%$ protein in milk) and calculating the milk formation capability, results in feed energy content for milk yields as shown in Table 7.

Feeding a ration with energy of $6.81 \mathrm{MJ}$ of $\mathrm{NE}_{\mathrm{L}} / \mathrm{kg}$ DM (determined at NL 1) and a DMI of $25 \mathrm{~kg}$, a milk yield from feed energy of $42.2 \mathrm{~kg}$ would be expected, without consideration of the remaining energetic impact. Considering the remaining energetic impact, dietary milk yield potential decreases to $37.9 \mathrm{~kg}$ at NL 6 ( $-4.3 \mathrm{~kg}$ of milk total, or $0.9 \mathrm{~kg}$ of milk per NL). Thereby the $\mathrm{NE}_{\mathrm{L}}$ requirement increases above the maintenance requirement from $3.14 \mathrm{MJ}$ of $\mathrm{NE}_{\mathrm{L}} / \mathrm{kg}$ of $\mathrm{FCM}$ at $\mathrm{NL} 1$ to $3.49 \mathrm{MJ}$ of $\mathrm{NE}_{\mathrm{L}} / \mathrm{kg}$ of $\mathrm{FCM}$ at NL 6 (0.07 MJ per NL).

It is obvious that the energetic feed value of a ration, or the energy requirement per kilogram of milk, clearly depends on the respective NL, and that this has to be considered up to NL 6 . Whether this is considered on the level of feed value or on the level of energy requirement per kilogram of FCM, has to be decided by useful reasons.

The GfE (2001) considers this impact on the level of requirement fixing per kilogram of milk. A requirement of $3.3 \mathrm{MJ}$ of $\mathrm{NE}_{\mathrm{L}} / \mathrm{kg}$ of ECM is deduced and defined for milk yields between 30 and $40 \mathrm{~kg} / \mathrm{d}$. This specification results from additional expenses of $0.8 \%$ per NL, which was calculated with $0.086 \mathrm{MJ} / \mathrm{kg}$ of FCM for $30 \mathrm{~kg}$ of FCM and with $0.106 \mathrm{MJ} / \mathrm{kg}$ of FCM for $40 \mathrm{~kg}$ of FCM. Thus, the fixed requirement of $3.3 \mathrm{MJ}$ of $\mathrm{NE}_{\mathrm{L}} / \mathrm{kg}$ of $\mathrm{FCM}$ is identical to the value for the $\mathrm{NL} 4$ (3.35 $\mathrm{MJ}$ of $\mathrm{NE}_{\mathrm{L}}$ / $\mathrm{kg}$ of FCM) presented in this study (Table 7).
The NL-dependent and differentiated $\mathrm{NE}_{\mathrm{L}}$ requirement per kilogram of FCM deduced in our investigations allows a better adjustment to the respective level of feeding or performance. Relating the remaining energetic impact for production of $40 \mathrm{~kg}$ of FCM (resulting from the decline of digestibility) to the DMI results in needing an additional DMI of $0.4 \mathrm{~kg}$ between the NL.

Nevertheless, henceforth it has to be considered that a substantial variation in $\mathrm{NE}_{\mathrm{L}}$ input per kilogram of FCM above the maintenance requirement exists within the dairy cattle population (with a trend of decreasing $\mathrm{NE}_{\mathrm{L}}$ input per kilogram of FCM at increasing performances). Hence, it is debatable whether the relation between the decrease of energy digestibility and the according partial compensation of the energy loss by concomitant reduction of the loss of methane energy and urine energy with rising NL, as used in Table 6, are still valid if the NL is higher than 3.5.

\section{CONCLUSIONS}

These studies confirm the decrease in digestibility of energy when NL increases to more than 3.5 in dairy cows. The rate of depression in digestibility of energy amounted to $4.1 \%$ for each increase in NL. Based on earlier investigations, the urinary energy and methane energy losses decrease with increasing NL. Taking into account the equations for calculating of urine and methane energy in relation to $\mathrm{NL}$, the $\mathrm{NE}_{\mathrm{L}}$ content declines only by $1.6 \%$ as the NL increased by one unit. The relationships between urinary and methane energy and the NL have not been investigated yet for NL higher than 3.5. For future investigations, analogous experiments with other ration ingredients, as well as higher or lower energy concentrations of the ration, in combination with whole metabolism measurements are also necessary for a more reliable and generally valid quantification of the problems related to the effect of the 
decline of digestibility on the adequate energy supply of high-yielding dairy cows.

\section{REFERENCES}

AFRC. 1993. Agricultural and Food Research Council: Energy and Protein Requirements of Ruminants. CAB International, Wallingford, UK.

Beever, D. E., D. J. Thomson, and S. B. Cammell. 1976. The digestion of frozen and dried grass by sheep. J. Agric. Sci. 86:443-452.

Brown, L. D. 1966. Influence of intake on feed utilization. J. Dairy Sci. 49:223-230.

Colucci, P. E., L. E. Chase, and P. J. Van Soest. 1982. Level of feed intake and diet digestibility in dairy cattle. J. Dairy Sci. 65:1445-1456.

Ekern, A. 1972. Feeding of high yielding dairy cows. IV. Ration digestibility in high yielding cows fed at different levels of intake. Sci. Rep. Agric. Univ. Norway 51(33):1-18.

Finger, T., H. Steingass, and W. Drochner. 1998. Einfluß von teilgeschützten Fetten in der Ration und Fütterungsniveau auf die Methanbildung bei Milchkühen. Proc. Soc. Nutr. Physiol. 7:48.

GfE. 2001. Ausschuß für Bedarfsnormen der Gesellschaft für Ernährungsphysiologie. Nr. 8 Empfehlungen zur Energie- und Nährstoffversorgung der Milchkühe und Aufzuchtrinder. DLG-Verlag Frankfurt a. Main, ISBN 3-7690-0591-0.

Goering, H. K., and P. J. Van Soest. 1970. Forage Fiber Analyses (Apparatus, Reagents, Procedures and Some Applications). Agric. Handbook No. 379. ARS-USDA, Washington, DC.

Hoffmann, L., and R. Schiemann. 1980. Von der Kalorie zum Joule: Neue Größenbeziehungen bei Messungen des Energieumsatzes und bei der Berechnung von Kennzahlen der energetischen Futterbewertung. Arch. Tiernähr. 30:733-742.

Jentsch, W., L. Hoffmann, and M. Beyer. 1993. Ergebnisse aus vergleichenden Untersuchungen von Parametern der Pansenfermentation und zur Verdaulichkeit von Futterrationen bei Rind und Schaf. 2. Zur Verdaulichkeit von Futterrationen. Arch. Anim. Nutr. 44:63-84.

Kuhla, S., A. Baumung, and F. Weissbach. 1983. Zur Rohfettbestimmung in Futtermitteln und Fäzes nach Salzsäureaufschluß. Arch. Tierernähr. 33:719-730.

Naumann, C., and R. Bassler. 1993. Die chemische Bestimmung von Futtermitteln. VDLUFA-Verlag Darmstadt.

NRC. 2001. National Research Council: Nutrient Requirements of Dairy Cattle. 7. rev. ed. Natl. Acad. Sci., Washington, DC.

Schiemann, R. 1981. Methodische Richtlinien zur Durchführung von Verdauungsversuchen für die Futterwertschätzung. Arch. Anim. Nutr. 31:1-19

Schiemann, R., W. Jentsch, H. Wittenburg, and L. Hoffmann. 1968. Ergebnisse vergleichender Untersuchungen über die Verdaulichkeit von Rationen bei Rind und Schaf unter besonderer Berücksichtigung pansenphysiologischer Parameter. Pages 867-876 in Wiss. Zeitschr. Univ. Rostock, math.-nat. Reihe 9/10.

Schiemann, R., W. Jentsch, L. Hoffmann, and H. Wittenburg. 1970. Die Verwertung der Futterenergie für die Milchproduktion. 1. Mitteilung: Untersuchungen an Tieren mit unterschiedlichem Leistungspotential. Arch. Tierernähr. 21:227-251.

Schiemann, R., W. Jentsch, and H. Wittenburg. 1971. Zur Abhängigkeit der Verdaulichkeit der Energie und der Nährstoffe von der Höhe der Futteraufnahme und der Rationszusammensetzung bei Milchkühen. Arch. Tierernähr. 21:223-240.

Tyrrell, H. F., and J. T. Reid. 1965. Prediction of the energy value of cows milk. J. Dairy Sci. 48:1215-1223.

Tyrrell, H. F., and P. W. Moe. 1975. Symposium: Production efficiency in the high producing cow. Effect of intake on digestion efficiency. J. Dairy Sci. 58:1151-1163.

Vermorel, M., and J. B. Coulon. 1998. Comparison of the National Research Council energy system for lactating cows for European systems. J. Dairy Sci. 81:846-855.

Zwierz, P., S. Kuhla, and F. Weißbach. 1981. Zur Schätzung des energetischen Futterwertes anhand von analytisch bestimmbaren Kriterien. Arch. Tierernähr. 31:395-399. 